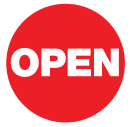

SUBJECT AREAS: PETROLOGY

GEOCHEMISTRY

MINERALOGY

GEODYNAMICS

Received

20 February 2013

Accepted

2 May 2013

Published

16 May 2013

Correspondence and requests for materials should be addressed to

Z.F.Y.

(yangzfeng2008@

163.com)

\section{Can we identify source lithology of basalt?}

\author{
Zong-Feng Yang \& Jun-Hong Zhou
}

State Key Laboratory of Geological Processes and Mineral Resources, China University of Geosciences, Beijing, 100083, China.

The nature of source rocks of basaltic magmas plays a fundamental role in understanding the composition, structure and evolution of the solid earth. However, identification of source lithology of basalts remains uncertainty. Using a parameterization of multi-decadal melting experiments on a variety of peridotite and pyroxenite, we show here that a parameter called $\mathrm{FC} 3 \mathrm{MS}$ value $\left(\mathrm{FeO} / \mathrm{CaO}-3 * \mathrm{MgO} / \mathrm{SiO}_{2}\right.$, all in wt\%) can identify most pyroxenite-derived basalts. The continental oceanic island basalt-like volcanic rocks $(\mathrm{MgO}>7.5 \%)(\mathrm{C}-\mathrm{OIB})$ in eastern China and Mongolia are too high in the FC3MS value to be derived from peridotite source. The majority of the C-OIB in phase diagrams are equilibrium with garnet and clinopyroxene, indicating that garnet pyroxenite is the dominant source lithology. Our results demonstrate that many reputed evolved low magnesian C-OIBs in fact represent primary pyroxenite melts, suggesting that many previous geological and petrological interpretations of basalts based on the single peridotite model need to be reconsidered.

\footnotetext{
- or years it was commonly assumed that basaltic magmas are derived from mantle peridotite ${ }^{1,2}$. Although several lines of evidence from multi-disciplines indicate that pyroxenite (unless otherwise stated, pyroxenite, including amphibolite, refers to mafic lithology that have a similar mineralogy as peridotite, but contains less than $40 \%$ olivine. From compositional perspective, pyroxenite and peridotite generally have $<30 \mathrm{wt} \%$ and $>30$ wt $\% \mathrm{MgO}$, respectively, see discussions in Supplementary Information) may play a critical role in the generation of basaltic magmas ${ }^{3-9}$, there is uncertainty about identification of source lithology of basalts because the current criteria such as high $\mathrm{Ni}$ content, high $\mathrm{Fe} / \mathrm{Mn}^{10,11}$ and $\mathrm{Zn} / \mathrm{Fe}$ ratios ${ }^{12}$, and low $\mathrm{CaO}$ content ${ }^{13}$ in either melts or olivine, which might also be interpreted as a result of peridotite compositional diversity and variations of melting and crystallizing conditions of basaltic magmas ${ }^{14-18}$ (Supplementary Information). On the other hand, isotope and trace elements cannot determine whether basalts are pyroxenite-derived melts or the pyroxenite signature just imprinted onto peridotite, although they might tell us the important role of pyroxenite ${ }^{19,20}$. Furthermore, the phase relations of basaltic melts, although can thermodynamically explain their overall compositional characteristics and melting pressures based on assumed source mineralogy, cannot constrain their source lithology and bulk composition ${ }^{17,19,21}$.
}

\section{Results}

FC3MS value can identify most pyroxenite-derived basalts. A large body of melting experiments on a variety of peridotite and pyroxenite at various melting conditions reported over the past three decades are parameterized in our study (Supplementary Figs. 1-5). In the commonly used simple plots, the pyroxenite melts, except for some low $\mathrm{MgO}(<5 \mathrm{wt} \%)$, high $\mathrm{SO}_{2}(>60 \mathrm{wt} \%)$, high $\mathrm{TiO}_{2}(>6 \mathrm{wt} \%)$ and high $\mathrm{FeO}(>15 \mathrm{wt} \%)$ melts, can overlap with peridotite melts if assuming that all the melts can be affected by olivine fractionation and accumulation. Importantly, the C-OIB can be grouped into either peridotite melts or pyroxenite melts in the simple plots and projections(Supplementary Figs. 1-4). This difficulty has also been realised by the recent review work of Lambart and co-workers ${ }^{22}$ on the markers of the pyroxenite contribution in the major element compositions of oceanic basalts, and which would commonly make us believe that the pyroxenite and peridotite melts are mostly indistinguishable and identification of source lithology of the C-OIB seems impossible based on major elements (Supplementary Information). Surprisingly, however, most pyroxenite melts can be identified because of their higher $\mathrm{FeO} / \mathrm{CaO}$ ratio (unless otherwise stated, $\mathrm{FeO}$ refers to total $\mathrm{FeO}$ ) at a given $\mathrm{MgO} / \mathrm{SiO}_{2}$ ratio, and the two ratios in general showing positive and negative correlations for peridotite and pyroxenite melts, respectively (Fig. 1a). Almost all the peridotite and pyroxenite melts, at a given pressure, showing negative correlations between $\mathrm{MgO} / \mathrm{SiO}_{2}$ and $\mathrm{FeO} / \mathrm{CaO}$ before clinopyroxene is melted out (Fig. 1). When volatiles such as $\mathrm{H}_{2} \mathrm{O}$, $\mathrm{CO}_{2}, \mathrm{CHO}$-fluid, and metasomatic minerals such as amphibole and phlogopite are present in peridotite source, 

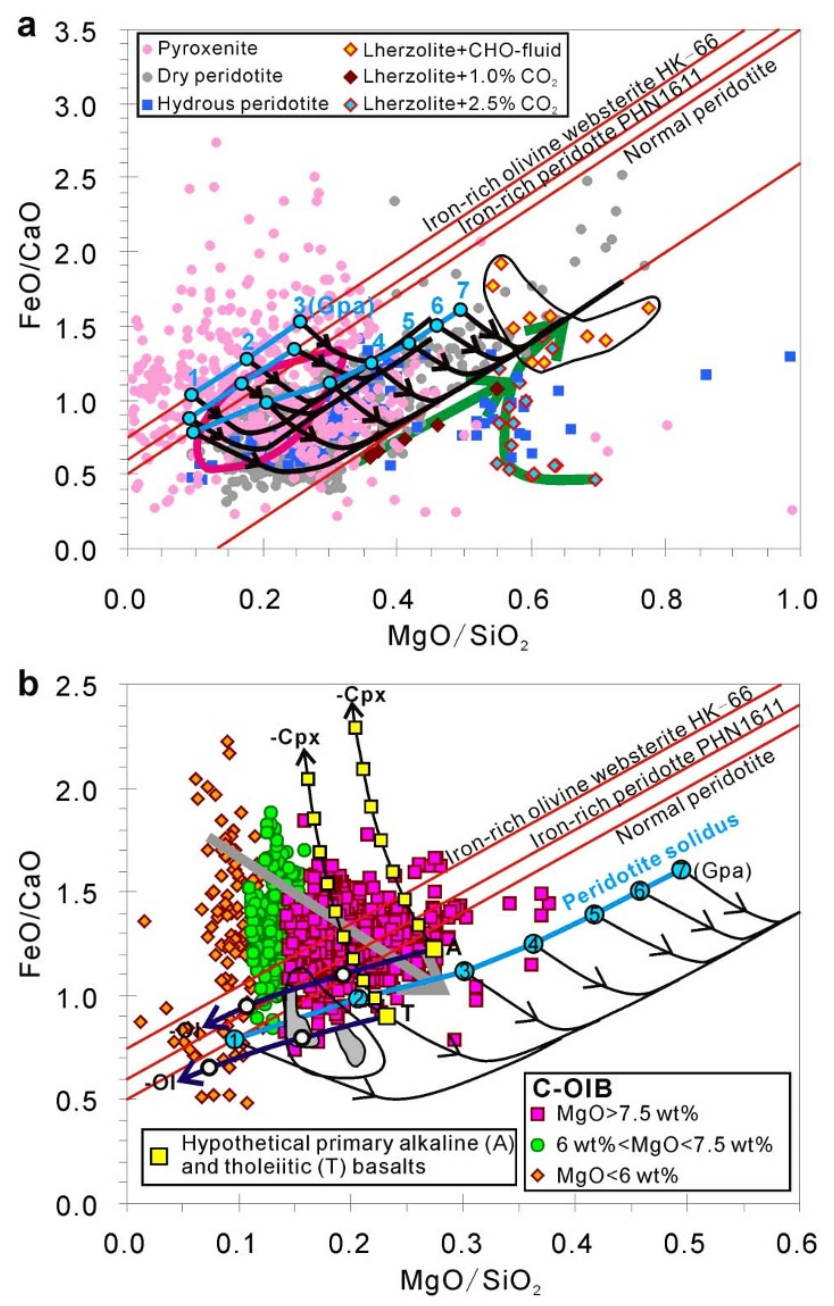

Figure $1 \mid \mathrm{FeO} / \mathrm{CaO}$ versus $\mathrm{MgO} / \mathrm{SiO}_{2}$ of experimental peridotite- and pyroxenite-derived melts and the C-OIB. (a), The four red line is the upper limit of near-solidus melts compositions for iron-rich olivine websterite (HK-66), iron-rich lherzolite (PHN1611), and normal lherzolite (KLB-1 and KR4003), and of melts that equilibrium with orthopyroxene and olivine, respectively. The numbered blue circles represent near-solidus melts compositions of the olivine websterite and peridotites from $1 \mathrm{Gpa}$ to $7 \mathrm{Gpa}$, and the black arrows refer to melting trends at constant pressure (Supplementary Figs. 8-10). The region depicted by red curve are volatile-free experimental peridotite melts with $\mathrm{Mg}^{*}=59.5 \sim 68.0$. (b), The grey arrow shows the overall melting trend of pyroxenite (Supplementary Fig. 11). The arrows with white circles and yellow squares, olivine $(\mathrm{Ol})$ and clinopyroxene $(\mathrm{Cpx})$ fractination trends (10 wt $\%$ step) of two hypothetical parental melts representing primary alkaline and tholeiitic C-OIB (Supplementary Table 1). Olivne fractionation trends were obtained using PRIMELT2 software ${ }^{35}$ and assuming $\mathrm{Fe}_{2} \mathrm{O}_{3} / \mathrm{TiO}_{2}=1$ in that the C-OIB might have high oxygen fugacity. It is commonly difficult to evaluate clinopyroxene fractionation, here we assume equilibrium crystallization and the partition coefficients of all major elements are estimated from our collected experimental results (Supplementary Table 1). The region depicted by the black curve shows EPR-MORB compositions ( $7.5 \mathrm{wt} \%$ $<\mathrm{MgO}<11 \mathrm{wt} \%$ ) acquired from EarthChem database and only those total iron content reported data are selected. The grey areas show the global average compositions of MORB including original compositions (higher FC3MS value) and corrected primary compositions (lower FC3MS value $)^{23}$. The C-OIB data acquired from GEOROCK database accessed December 2012 (Supplementary Table 2). Other data source given in Supplementary Information. the resultant melts FC3MS values are either equal to or lower than that of volatile-free peridotite melts (Fig. 1 and Supplementary Figs. 12 and 13). The parameterized results of experimental peridotite melts shown in Fig. 1 also applied to theoretical calculations (Supplementary Fig. 13). In addition, the $\mathrm{MgO} / \mathrm{SiO}_{2}$ and $\mathrm{FeO} / \mathrm{CaO}$ ratios of the peridotite melts in general are positively correlated with pressure (Supplementary Fig. 14), which is very similar as the pressure effect on $\mathrm{FeO} / \mathrm{MnO}$ ratio (Supplementary Fig. 15), but the FC3MS value $\left(\mathrm{FeO} / \mathrm{CaO}-3 * \mathrm{MgO} / \mathrm{SiO}_{2}\right.$, all in wt\%) is pressureindependent (Supplementary Fig. 16).

The near-solidus melts of iron-rich lherzolite PHN1611 is estimated with FC3MS $\sim 0.60$ (Fig. 1), and which is found to be the highest FC3MS value for all the experimental lherzolite melts (Figs. 1-2). The FC3MS value of normal mantle lherzolite melts is estimated less than 0.5 (Fig. 1). It should be noted that the FC3MS value of lherzolite melts is largely dependent on total alkali content and melting degree (Fig. 2a, c). The FC3MS values of most pyroxenite melts can significantly higher than peridotite melts at the same total alkali content, melting degree and $\mathrm{Mg}^{\#}(\mathrm{MgO} /(\mathrm{MgO}+\mathrm{FeO}) * 100$, molar ratio), and can also higher than the near-solidus peridotite melts even if pyroxenite have very high degree partial melting ( $\sim 20 \%-50 \%)$ (Fig. 2c). Noteworthy is the wide range of $\mathrm{Mg}^{*}$ for both peridotite and pyroxenite melts, although it is commonly assumed that mantle-derived primary magmas have $\mathrm{Mg}^{\#} \sim 70-73$. Nevertheless, pyroxenite melts can have very broad range of $\mathrm{Mg}^{*}$, at least ranging from 40 to 70 (Fig. 2b). Therefore mantle-derived primary magmas would not necessarily have high $\mathrm{Mg}^{\#}$, and which of course can show large variations in both $\mathrm{Mg}^{*}$ and $\mathrm{MgO}$ content if we do not assume that basaltic magmas are equilibrium with typical mantle peridotite. Using the systematic variations of the FC3MS values versus $\mathrm{Na}_{2} \mathrm{O}+\mathrm{K}_{2} \mathrm{O}$ (wt\%), $\mathrm{Mg}^{*}(\mathrm{MgO} /(\mathrm{MgO}+\mathrm{FeO}) * 100$, molar ratio) and melting degree (F\%) of a variety of peridotite melts (Supplementary Figs. 17-23), we determined the upper limit of the FC3MS value for olivine-controlled fractionated peridotite melts after $\sim 10-30 \mathrm{wt} \%$ olivine fractionation when $\mathrm{MgO}>7.5 \mathrm{wt} \%$ or $\mathrm{Mg}^{\#}>50$ (Fig. $2 \mathrm{~b}$ and Supplementary Fig. 20). Simply, for peridotite melts the upper limit of the FC3MS value is 0.65 . Our statistical results show that the experimental peridotite- and pyroxenitederived melts are $-0.07 \pm 0.51(2 \delta, \mathrm{n}=656)$ and $0.46 \pm 0.96(2 \delta$, $\mathrm{n}=494$ ) in the average FC3MS value, respectively (Supplementary Fig. 24a, b and Supplementary Table 3).

Peridotite melts cannot explain the FC3MS value of most C-OIB. Interestingly, the C-OIB (unless otherwise stated, the C-OIB refers to samples that have $\mathrm{MgO}>7.5 \mathrm{wt} \%$ throughout the remainder of the paper) FC3MS $=0.68 \pm 0.34(2 \delta, \mathrm{n}=525)$, the alkaline C-OIB FC3MS $=0.65 \pm 0.35(2 \delta, \mathrm{n}=356)$ and the tholeiitic C-OIB FC3MS $=0.70 \pm 0.30(2 \delta, n=138)$ (Supplementary Figs. $24 \mathrm{c}, \mathrm{d}$ and 25 and Supplementary Table 3), of which more than half samples have higher FC3MS value than the upper limit of peridotite melts, but all the C-OIB FC3MS values fall in the range of pyroxenite melts (Figs. 1-3). The FC3MS values of the C-OIB are not correlated with major element contents of $\mathrm{SiO}_{2}, \mathrm{TiO}_{2}, \mathrm{Al}_{2} \mathrm{O}_{3}$ and $\mathrm{FeO}$, but showing weak negative correlations with $\mathrm{MgO}$ and $\mathrm{CaO}$ contents. In particular, the low $\mathrm{SiO}_{2}(<43 \mathrm{wt} \%)$ and high $\mathrm{FeO}(>13.5 \mathrm{wt} \%) \mathrm{C}$ OIB show relative lower FC3MS values (generally less than 0.65 ), although having the most significant differences relative to peridotite melts in simple plots (Supplementary Figs. 1-3). Nevertheless, these samples still significantly differ from all the known peridotite melts when presented in Fig. 3a. Because there is an upper limit for the FC3MS value of the peridotite melts (Figs. 1-3), isobaric melting, polybaric melting, or melt mixing from various kinds of conditions, the resultant FC3MS values of peridotite melts still cannot higher than 0.65 (Supplementary Figs. 21-22). The high FC3MS values of these relative primitive $\mathrm{C}$-OIBs might be explained by substantial amount fractionation of clinopyroxene or pyroxenite 

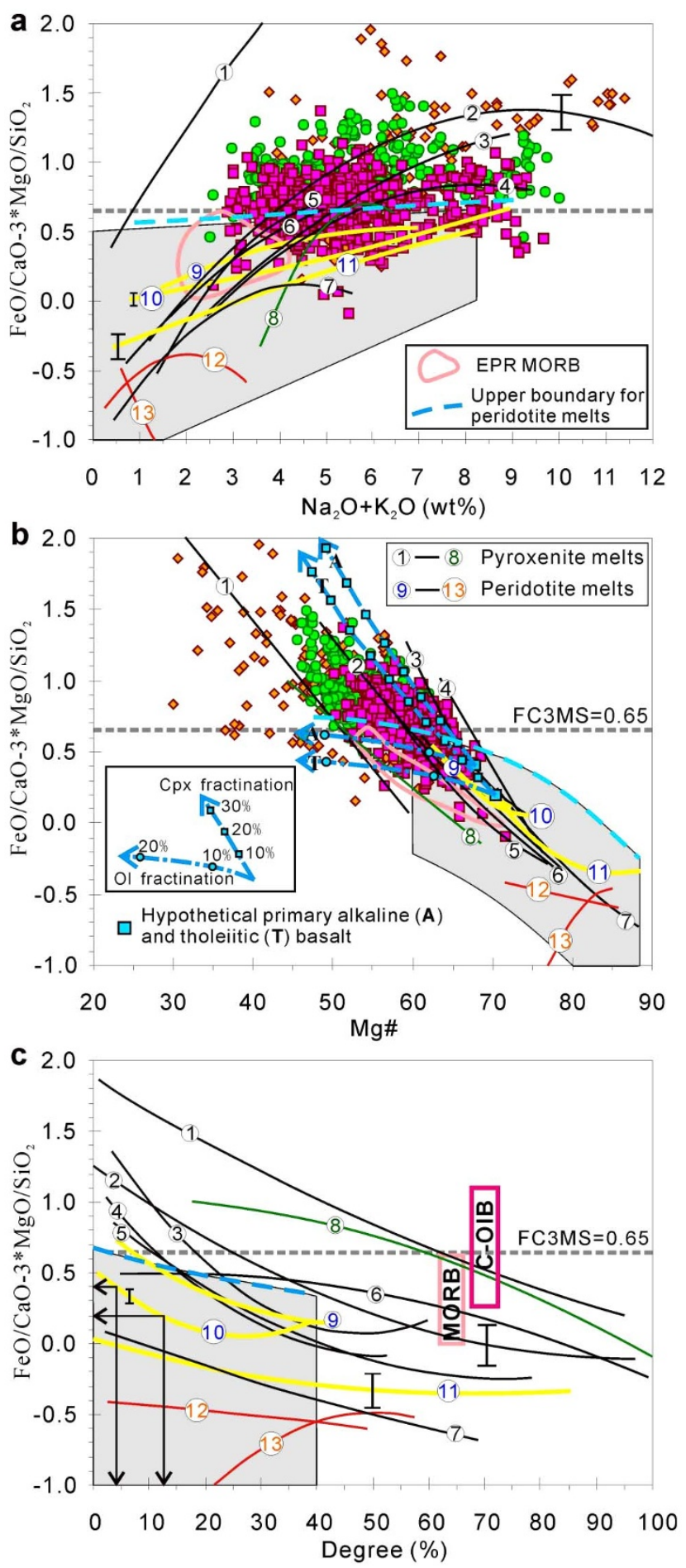

Figure 2 Diagrams showing the FC3MS value as functions of $\mathrm{Na}_{2} \mathrm{O}+$ $\mathrm{K}_{2} \mathrm{O}, \mathrm{Mg}^{*}$ and melting degree (\%). For clarity, only the C-OIB data and melting trends of thirteen representative peridotite and pyroxenite are shown. Detailed data point and data source given in Supplementary Figs. 17-19. Grey areas in (a), (b) and (c) are peridotite melts $\left(\mathrm{Mg}^{\#}>60\right)$. The error bars shown in (a) and (c) are the standard deviation for average pyroxenite melts and normal and enriched peridotite melts.

partial melting. Before presenting our preferred interpretation, we discuss why clinopyroxene fractionation of peridotite melts cannot reasonably explain the high FC3MS values of the C-OIB.

For the peridotite model of basalts, it is widely accepted that alkaline basalts are lower degree partial melts than tholeiitic basalts. Here we assume that the $\sim 4 \%$ and $\sim 13 \%$ partial melts of iron-rich peridotite PHN1611 represent the primary alkaline and tholeiitic basalts of the C-OIB (Fig. 2c), and their FC3MS values are estimated $\sim 0.4$ and $\sim 0.2$, respectively (detailed hypothetical composition see Supplementary Table 1). For peridotite source the hypothetical FC3MS values can be regarded as the upper limit of the primary $\mathrm{C}-\mathrm{OIB}$, which higher than most primary $\mathrm{MORB}^{23}$ (Fig. 1b). In order to explain the FC3MS values and major element contents of the COIB, we need assume $\sim 0-15$ wt $\%$ olivine fractionation combined with $\sim 30-40 \mathrm{wt} \%$ and $\sim 60-70 \mathrm{wt} \%$ clinopyroxene fractionation for the alkaline C-OIB and tholeiitic C-OIB, respectively (Figs. 1-3). Nevertheless, if the C-OIB are indeed evolved magmas the fractionating mineral should be mainly olivine rather than clinopyroxene. First, ascent and decompression of peridotite melts would cause olivine oversaturated and pyroxene undersaturated. It is difficult for peridotite melts with $\mathrm{MgO}>7.5 \mathrm{wt} \%$ to crystallize clinopyroxene. Many previous studies suggested that the C-OIB mostly contain only olivine phenocrysts or aphanitic ${ }^{24-27}$, which are the characteristic features even for the C-OIB with $\mathrm{MgO}<7.5 \mathrm{wt} \%{ }^{27}$. In particular, the alkaline C-OIB generally carry a variety of mantle-derived xenoliths, indicating that magma evolution is very limited during ascent in crustal conduits. Second, olivine is commonly the dominant fractionating mineral for basaltic magmas, including MORB and OIB, when $\mathrm{MgO}>7.5 \mathrm{wt} \%{ }^{13,28}$. The C-OIB generally have higher alkali and lower $\mathrm{CaO}$ contents than MORB at a given MgO content (Supplementary Fig. 4), which would expand the stability field of olivine at the expense of clinopyroxene, giving rise to clinopyroxene crystalliation in the $\mathrm{C}-\mathrm{OIB}$ at lower $\mathrm{MgO}$ content than that for MORB.

Although the high Fe/Mn ratios of the C-OIB might be explained by high pressure partial melting of peridotite or as characteristics of iron-rich or high $\mathrm{Fe} / \mathrm{Mn}$ peridotite melts ${ }^{15,16}$, the negative correlation between $\mathrm{Fe} / \mathrm{Mn}$ ratios and $\mathrm{Yb}$ contents of the $\mathrm{C}$-OIB in north China craton is inconsistent with significant fractionation of clinopyrox$e^{2} \mathrm{e}^{26}$. Importantly, even for those C-OIB with $\mathrm{MgO}>10 \mathrm{wt} \%$ and those with $\mathrm{Mg}^{*}>60$, their average FC3MS values are $0.54 \pm 0.31(2 \delta$, $\mathrm{n}=135)$ and $0.57 \pm 0.32(2 \delta, \mathrm{n}=238)$, respectively (Supplementary Table 3). Nearly half of these primitive C-OIB still have higher FC3MS values than the peridotite melts. Note that the wide range in the FC3MS value of the peidotite melts include $\mathrm{Mg}^{\#}=60 \sim 68$ melts (Fig. 2b and Supplementary Fig. 20). Therefore, it is highly unrealistic to assume $\sim 30-70 \mathrm{wt} \%$ fractionation of clinopyroxene for explaining the high FC3MS values of the C-OIB. It should also be noted, however, that many previous studies using $\mathrm{MgO}>6 \mathrm{wt} \% \mathrm{C}$ OIB to acquire primary melts composition that equilibrium with peridotite using olivine addition method ${ }^{25,29}$. Although the calculation is not carried out in this study, the C-OIB with $\mathrm{MgO}>6 \mathrm{wt} \%$ are significantly deviated from the olivine fractionation trends of peridotite melts (Fig. 2b), and even for the alkaline C-OIB the elevated FC3MS values require $\sim 50-70$ wt $\%$ clinopyroxene fractionation, which not only rather unrealistic but also contradicts the initial assumption of olivine-controlled fractionation.

The global MORB glass compositions ( $\mathrm{MgO}>7 \mathrm{wt} \%)$ show that the highest increase of the FC3MS values is 0.47 relative to corrected primary melts that equilibrium with typical mantle peridotite, and for MORB with $\mathrm{MgO}>7.5 \mathrm{wt} \%$, the increase of $\mathrm{FC} 3 \mathrm{MS}$ value is universally lower than $0.3^{23}$. Therefore if assuming that these MORB glass and the C-OIB are peridotite-derived and underwent a similar fractionation process, the tholeiitic (assuming primary melt with FC3MS $=0.2$ ) and alkaline (assuming primary melt with FC3MS $=0.4$ ) $\mathrm{C}$-OIB then would have FC3MS values less than 0.5 and 0.7 , respectively. In addition, the EPR-MORB (MgO>7.5 wt\%) with FC3MS $=0.33 \pm 0.20(2 \delta, \mathrm{n}=1510)($ Supplementary Table 3$)$, which is significantly lower than the C-OIB $(0.68 \pm 0.34(2 \delta, \mathrm{n}=$ $525)$ ). Noteworthy is the FC3MS values of the EPR-MORB increase from $\sim 0.35$ to $\sim 0.65$ when $\mathrm{MgO}$ content decrease from $8.5 \mathrm{wt} \%$ to $7.5 \mathrm{wt} \%$, which accompanied by decrease of $\mathrm{Al}_{2} \mathrm{O}_{3}$ and $\mathrm{CaO}$ contents and increase of $\mathrm{FeO}$ and $\mathrm{TiO}_{2}$ contents. These variations are very 

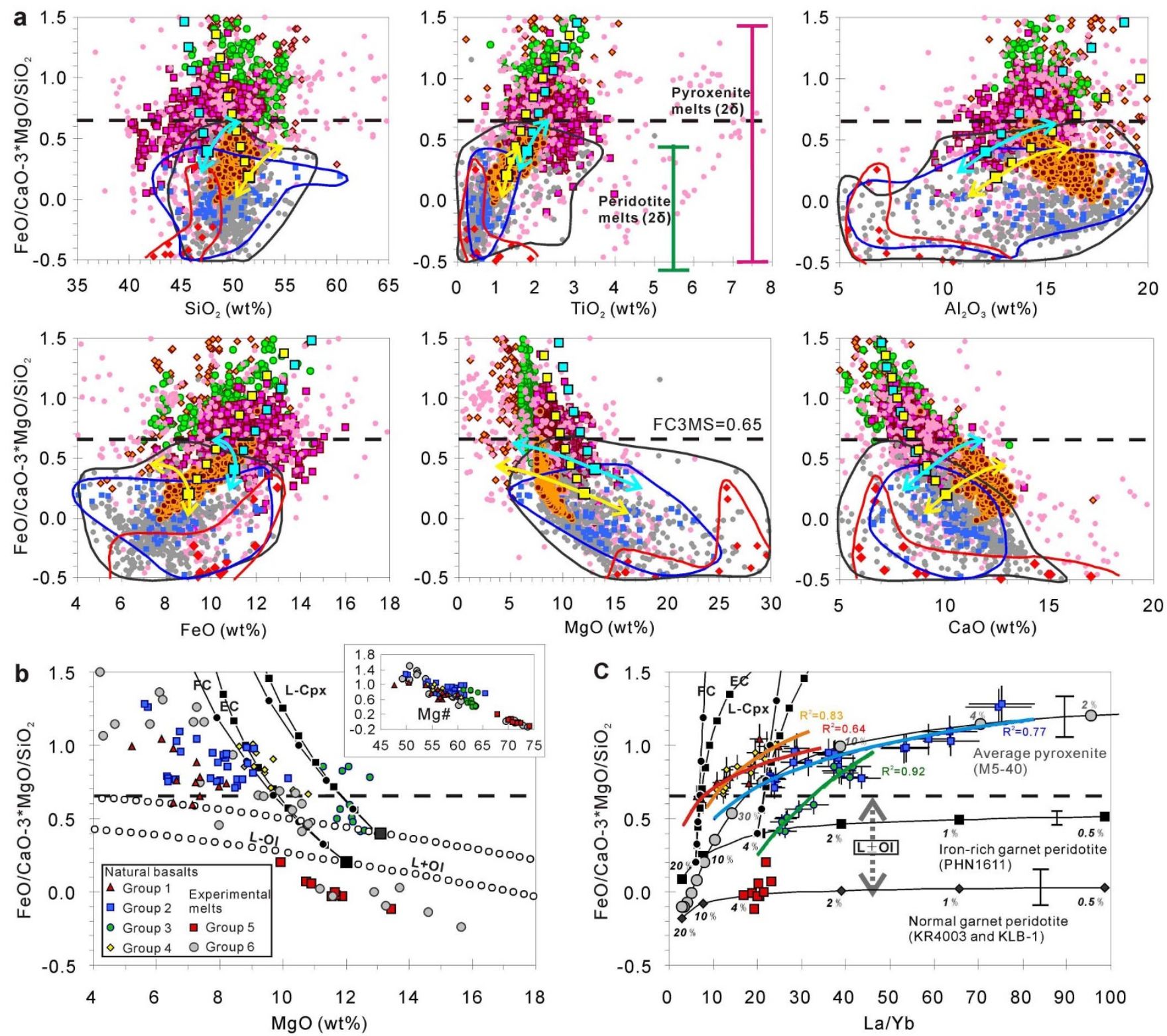

Figure 3 FC3MS values versus major elements contents and $\mathrm{La} / \mathrm{Yb}$ of the $\mathrm{C}$-OIB and experimental peridotite- and pyroxenite-derived melts. (a), The blue and yellow arrows showing the fractionation (increasing the FC3MS value) and accumulation (decreasing the FC3MS value) trends of olivine. The blue and yellow filled squares showing the fractionation trends of clinopyroxene, of which the larger squares represent the hypothetical primary magmas, blue, alkaline basalt, yellow, tholeiitic basalt. The brown filled circles, EPR-MORB compositions $(7.5 \mathrm{wt} \% \leq \mathrm{MgO}<11 \mathrm{wt} \%)$. The red filled diamond, $\mathrm{CO}_{2}$ and $\mathrm{CHO}$ fluid present peridotite melts. (b), Group 1, Fujian tholeiitic basalt ${ }^{30}$. Group 2, Tariat alkaline basalt ${ }^{27}$. Group 3 and group 4, Shuangliao alkaline basalt ${ }^{31}$. All the four groups data see supplementary Table 4 . Group 5 and group 6 are experimental hornblende peridotite ${ }^{32}$ and garnet pyroxenite melts $^{36,37}$, respectively. Olivine fractionation and accumulation, $1 \mathrm{wt} \%$ step. Fractional (FC) and equilibrium (EC) clinopyroxene crystallization, $10 \mathrm{wt} \%$ step. The FC3MS values of the melts of the three source rocks are estimated by the relationships between FC3MS value and melting degree shown in Fig. 2c. The La/Yb ratios are caculated by batch melting model, modeling parameters see Supplementary Table 6 . The correlation coefficients $\left(\mathrm{R}^{2}\right)$ calculated using logarithmic line. The assumed error bars of the natural basalts represent $\pm 10 \%$ variation of the FC3MS values and La/Yb ratios, which probably result from many secondary factors including partial melting conditions, magma evolution, analytical error and source compositional diversity etc. Other explanations same as in Fig. 1.

similar as fractionation trends of olivine and clinopyroxene and plagioclase, however, which can also be attributed to the contributions from the pyroxenite melts (Fig. 3a), but currently it is difficult to verify and estimate the proportion of the pyroxenite melts because of the wide variations in the melts compositions for the heterogeneous peridotite and pyroxenite sources.

In Fig. 3b, for peridotite model, the negative correlations between the FC3MS value and $\mathrm{MgO}$ content of the selected four groups C$\mathrm{OIB}^{27,30,31}$ can be readily explained as the result of different degrees fractionation of olivine and clinopyroxene, and the group 3 and group 4 data seem result from clinopyroxene-dominated fractionation. However, pyroxenite melts (group 6) also can produce these trends. And, it is difficult for such high $\mathrm{MgO}$ melts (for example, group 3, $\mathrm{MgO}=8.6-10.8 \mathrm{wt} \%$; group $4, \mathrm{MgO}=11.3-12.8 \mathrm{wt} \%)$ to crystallize clinopyroxene. The most important evidence to support pyroxenite source is that the significant positive correlations between the FC3MS value and $\mathrm{La} / \mathrm{Yb}$ ratio for each group data are in good agreement with the melting trend of model average pyroxenite (Fig. 3c). The pyroxenite melting trends can only be explained by crystallization process of peridotite melts when assuming that 
clinopyrxene or other fractionating minerals (for example, plagioclase) have extremely high mineral/melt partition coefficient of $\mathrm{Yb}$, just as garnet, but this is rather unrealistic. In addition, the hornblende peridotite, may represent metasomatized peridotite, cannot produce high FC3MS value melts, although it can produce high $\mathrm{La} /$ $\mathrm{Yb}$ ratio melts (group 5) ${ }^{32}$. The simultaneous consideration of FC3MS versus $\mathrm{MgO}$ and FC3MS versus $\mathrm{La} / \mathrm{Yb}$ in Fig. 3b, c suggests that many reputed evolved low magnesian $\left(\mathrm{MgO}, \sim 4-10 \mathrm{wt} \%, \mathrm{Mg}^{*}\right.$, $\sim 50-60$ ) C-OIBs in fact represent primary pyroxenite melts. These low magnesian primary magmas might also be present in various types of basalts such as typical ocean island basalt and continental flood basalt, although they are commonly deemed as evolved magmas. Thus it should be cautious about using olivine-correction method to gain high magnesian primary magmas that equilibrium with typical mantle peridotite. One important consequence is that corrected high magnesian magma would overestimate mantle potential temperature, a similar conclusion had been reached by Presnall and Gudfinnsson ${ }^{17}$.

Phase relation constraints on the C-OIB. Trace elements suggest that the C-OIB have the typical garnet signature, which commonly are attributed to various degrees mixing between garnet lherzolite melts and spinel lherzolite melts ${ }^{25,29}$. This explanation seems to be supported by projections in phase diagrams where the C-OIB, except for some highly alkaline basalts, overlap with volatile-free peridotite melts (Fig. 4). Note that olivine fractionation in Fig. 4a will increase the overlap between the C-OIB and volatile-free peridotite melts. Nevertheless, all the peridotite melts cannot explain the high FC3MS values and the relationship between the FC3MS values and $\mathrm{La} / \mathrm{Yb}$ ratios of the C-OIB (Fig. 3). Therefore, the projections of the C-OIB in Fig. 4 indicate that they are mostly partial melts of garnet pyroxenite formed on the cotectic $[\mathrm{L}+\mathrm{Cpx}+\mathrm{Gt}]$. Note that the cotectic $[\mathrm{L}+\mathrm{Cpx}+\mathrm{Gt}]$ may also contain small amount of spinel, olivine and orthopyroxene, because of variations in source bulk composition, melting degree and pressure. Note also that the 1.6 2 Gpa cotectics $[\mathrm{L}+\mathrm{Ol}+\mathrm{Cpx}+\mathrm{Opx}+\mathrm{Gt}]$ of hydrous peridotite are similar as the alkaline C-OIB projections, whereas the $3 \mathrm{Gpa}$ cotectic $[\mathrm{L}+\mathrm{Ol}+\mathrm{Cpx}+\mathrm{Gt}]$ of hydrous peridotite richer in diopside component than that of volatile-free peridotite (Supplementary Fig. 26b). Although hydrous peridotite at 1.6 2 Gpa can make garnet stable and generate melts that overlap with the C-OIB projections in the phase diagrams (Fig. 4), the FC3MS values of these hydrous melts are too low $(\sim-0.12-$ $0.01)^{33}$ to explain the high FC3MS values of the C-OIB. Therefore, hydrous peridotite should not be a good candidate for the C-OIB source.

For the garnet pyroxenite melts formed on the cotectic $[\mathrm{L}+\mathrm{Cpx}$ $+\mathrm{Gt}$ ], one important characteristic is that the melts projections no longer record their detailed generation pressures (Supplementary Fig. 27). The tholeiitic C-OIB might be generated at similar or even higher pressures than the alkaline C-OIB. These pressure information acquired from the pyroxenite model are significantly different from those based on peridotite model, where alkaline basalts are typically assumed to be generated at higher pressures and lower melting degrees than tholeiitic basalts ${ }^{24,25,29}$. In addition, even for the cotectic $[\mathrm{L}+\mathrm{Ol}+\mathrm{Cpx}+\mathrm{Gt} \pm \mathrm{Opx}]$, the pressure information still can be significantly affected by addition of $\mathrm{CO}_{2}$, but these melts have too much diopside component than the C-OIB (Supplementary Fig. 28). The highly silica undersaturated C-OIB are also very similar as carbonated garnet pyroxenite- and hornblendite-derived melts (Supplementary Figs. 27 and 28), indicating that their source might contain $\mathrm{CO}_{2}$, hornblende and phlogopite etc.

\section{Discussion}

The best and our preferred explanation is that the C-OIB are mainly, if not all, pyroxenite melts. The pyroxenite melts with low $\mathrm{Mg}^{\#}$ and
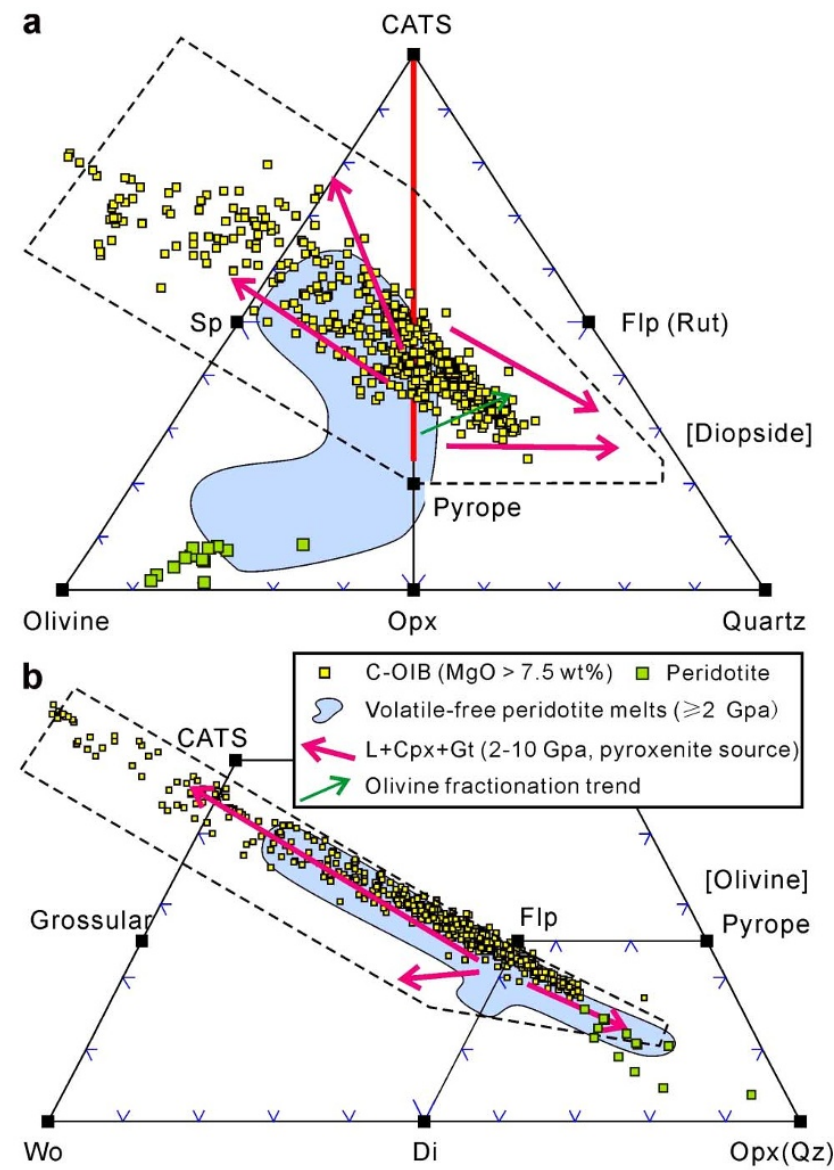

Figure $4 \mid$ Projections (mole\%) of the C-OIB compared with experimental melts that equilibrium with garnet pyroxenite and peridotite. (a), A projection from or towards Diopside into the plane Olivine-Quartz-Calcium Tschermak's. (b), A projection of the same data as in (a) from or towards Olivine into a part of the garnet-pyroxene plane. This pyroxene-garnet plane is represented as the Opx-CATS line in (a). Projection code is from ref. 2 (see Supplementary Fig. 4). The regions depicted by dashed line are the potential basaltic melts that equilibrium with garnet pyroxenite, and the red arrows indicates the direction of decreasing temperature of melts that equilibrium with major residual phases, garnet and clinopyroxene. The peridotites shown in (a) and (b) are the source rocks of the volatile-free peridotite melts ( $\geq 2 \mathrm{Gpa}$ ). The detailed projections presented in Supplementary Figs. 4, 26 and 27. CATS$\mathrm{CaAl}_{2} \mathrm{SiO}_{6}$, Diopside- $\mathrm{Ca}(\mathrm{Mg}, \mathrm{Fe}) \mathrm{Si}_{2} \mathrm{O}_{6}$, Olivine- $(\mathrm{Mg}, \mathrm{Fe})_{2} \mathrm{SiO}_{4}, \mathrm{Opx}$ (Enstatite)- (Mg, $\mathrm{Fe})_{2} \mathrm{Si}_{2} \mathrm{O}_{6}$, Quartz- $\mathrm{SiO}_{2}$, Grossular- $\mathrm{Ca}_{3} \mathrm{Al}_{2} \mathrm{Si}_{3} \mathrm{O}_{12}$, Pyrope- $(\mathrm{Mg}, \mathrm{Fe})_{3} \mathrm{Al}_{2} \mathrm{Si}_{3} \mathrm{O}_{12}$, Wo- $\mathrm{CaSiO}_{3}$, Flp- $(\mathrm{Na}, \mathrm{Ca})(\mathrm{Si}, \mathrm{Al})_{4} \mathrm{O}_{8}$ or $(\mathrm{Na}$, $\mathrm{K}) \mathrm{AlSi}_{3} \mathrm{O}_{8}$, Rut- $\mathrm{TiO}_{2}, \mathrm{Sp}-\mathrm{MgAl}_{2} \mathrm{O}_{4}$.

high alkali contents are experimentally characterized by very low temperatures, even lower than the normal mantle peridotite solidus ${ }^{6}$. When the pyroxenite partially melt to produce basaltic magmas that have similar compositions as the C-OIB, the mantle peridotite may still subsolidus, the pyroxenite melts, however, can have higher melting degree than commonly assumed peridotite melts (Supplementary Information), and thus might have much stronger migration ability. This probably is one of the most important reasons that the C-OIB, without equilibrium with mantle peridotite, can record the characteristics of pyroxenite melts although carrying a variety of crustal and mantle xenoliths. Therefore the garnet pyroxenite would partially melt when mantle decompression or asthenosphere upwelling occurs at normal mantle potential temperature. This process does not need the high temperature mantle plume model ${ }^{34}$ (Supplementary Information). 
The C-OIB have broadly chemical similarities and small in volume although temporally and spatially widely distributed ${ }^{24,25,29}$. This is likely to be the characteristic features of continental pyroxenitederived melts as a result of mantle lithological heterogeneity after long periods recycling of continental crust ${ }^{8}$. The two-component marble-cake mantle model ${ }^{4}$ or the statistical upper mantle assemblage model $^{7}$ might better characterize the continental upper mantle and seems to be supported by the pyroxenite-derived C-OIB. Importantly, because there are significant differences with regard to the petrogenesis of peridotite- and pyroxenite-derived basalts, many previous geological and petrological interprations of the COIB based on the peridotite mode ${ }^{24,25,29}$ need to be reconsidered.

In conclusion, we propose that the FC3MS value is a useful criterion for identification of source lithology of basalts even if taking into account source compositional diversity and variation of melting and crystallization conditions of basaltic magmas. This discriminant parameter provides a new perspective to understand the compositional characteristics of basalts and also provides insight into the origin of basalts.

\section{Methods}

In trying to find the taxonomical criterion of source lithology of basalts, we have collected nearly all the experimental melts on a variety of peridotite and pyroxenite in literature before the year 2013. Note that our selected peridotite melts are not exclusively on volatile-free or normal mantle peridotite. All the experimental melts and C-OIB are carefully examined using simple plots, projections and FC3MS-based diagrams. The parameterization results of several representative perdotite and pyroxenite melting trends are presented and explained in Supplementary Figures 8-11. Other details about the data selection and sources of experiments and the C-OIB and the parameterization are presented in Supplementary Information and Figures 1-3.

We do not assume either peridotite or pyroxenite end-member source composition for mantle-derived magmas, but they can be roughly divided into two lithological units using their whole-rock $\mathrm{MgO}$ contents. Although the majority of the experiments are batch melting results, our parameterized FC3MS value would not change significantly for accumulated fractional melting (Supplementary Fig. 22). Importantly, our main conclusion that garnet pyroxenite is the dominant source lithology for the C-OIB is based on a safely upper limit of FC3MS value $\sim 0.65$, which approximate to near-solidus melts of iron-rich peridotite. If peridotite melts are mixed products from a variety of peridotite under various conditions (e.g. volatilefree and volatile present), the resultant melts still have FC3MS values less than 0.65 (Supplementary Information). Nevertheless, the magma mixing mechanism would easily change the major element content, which might be the reason that peridotite and pyroxenite melts cannot be distinguished in the commonly used Harker diagrams and phase diagrams. Although olivine chemistry method ${ }^{10,19}$ has been widely used to identify pyroxenite melts, it might introduce many uncertainties due to source compositional diversity and melting and crystallizing conditions before enough high precision experiments achieved (Supplementary Information). For some low-magnesium C-OIB, high FC3MS, high Fe/Mn ratios and low $\mathrm{CaO}$ contents might result from fractionation of clinopyroxene and olivine, but pyroxenite melting trends can be indicated by FC3MS and $\mathrm{La} / \mathrm{Yb}$ relations (Fig. 3).

1. Yoder, H. S. \& Tilley, C. E. Origin of basalt magmas: an experimental study of natural and synthetic rock systems. Journal of Petrology 3, 342 (1962).

2. O'hara, M. The bearing of phase equilibria studies in synthetic and natural systems on the origin and evolution of basic and ultrabasic rocks. Earth-Sci Rev 4, 69-133 (1968).

3. Hofmann, A. W. \& White, W. M. Mantle Plumes from Ancient Oceanic-Crust. Earth and Planetary Science Letters 57, 421-436 (1982).

4. Allegre, C. J. \& Turcotte, D. L. Implications of a two-component marble-cake mantle. Nature 323, 123-127 (1986).

5. Hirschmann, M. M. \& Stolper, E. M. A possible role for garnet pyroxenite in the origin of the "garnet signature" in MORB. Contributions to Mineralogy and Petrology 124, 185-208 (1996).

6. Kogiso, T., Hirschmann, M. M. \& Pertermann, M. High-pressure partial melting of mafic lithologies in the mantle. Journal of Petrology 45, 2407-2422 (2004).

7. Meibom, A. \& Anderson, D. L. The statistical upper mantle assemblage. Earth and Planetary Science Letters 217, 123-139 (2004).

8. Anderson, D. L. Large igneous provinces, delamination, and fertile mantle. Elements 1, 271-275 (2005).

9. Hauri, E. H. Major-element variability in the Hawaiian mantle plume. Nature 382 , 415-419 (1996).

10. Sobolev, A. V., Hofmann, A. W., Sobolev, S. V. \& Nikogosian, I. K. An olivine-free mantle source of Hawaiian shield basalts. Nature 434, 590-597 (2005).

11. Sobolev, A. V. et al. The amount of recycled crust in sources of mantle-derived melts. Science 316, 412-417 (2007).
12. Le Roux, V., Dasgupta, R. \& Lee, C. T. A. Mineralogical heterogeneities in the Earth's mantle: Constraints from $\mathrm{Mn}, \mathrm{Co}, \mathrm{Ni}$ and $\mathrm{Zn}$ partitioning during partial melting. Earth and Planetary Science Letters 307, 395-408 (2011).

13. Herzberg, C. Petrology and thermal structure of the Hawaiian plume from Mauna Kea volcano. Nature 444, 605-609 (2006).

14. Li, C. S. \& Ripley, E. M. The relative effects of composition and temperature on olivine-liquid Ni partitioning: Statistical deconvolution and implications for petrologic modeling. Chemical Geology 275, 99-104 (2010).

15. Putirka, K., Ryerson, F. J., Perfit, M. \& Ridley, W. I. Mineralogy and Composition of the Oceanic Mantle. Journal of Petrology 52, 279-313 (2011).

16. Niu, Y. L., Wilson, M., Humphreys, E. R. \& O’Hara, M. J. The Origin of Intra-plate Ocean Island Basalts (OIB): the Lid Effect and its Geodynamic Implications. Journal of Petrology 52, 1443-1468 (2011).

17. Presnall, D. C. \& Gudfinnsson, G. H. Oceanic Volcanism from the Low-velocity Zone - without Mantle Plumes. Journal of Petrology 52, 1533-1546 (2011).

18. Rhodes, J. M., Huang, S., Frey, F. A., Pringle, M. \& Xu, G. Compositional diversity of Mauna Kea shield lavas recovered by the Hawaii Scientific Drilling Project: Inferences on source lithology, magma supply, and the role of multiple volcanoes. Geochem. Geophys. Geosyst. 13, Q03014 (2012).

19. Herzberg, C. Identification of Source Lithology in the Hawaiian and Canary Islands: Implications for Origins. Journal of Petrology 52, 113-146 (2011).

20. Prytulak, J. \& Elliott, T. TiO2 enrichment in ocean island basalts. Earth and Planetary Science Letters 263, 388-403 (2007).

21. Green, D. H. \& Falloon, T. J. Primary magmas at mid-ocean ridges, "hot spots" and other intraplate settings: Constraints on mantle potential temperature. Plates, Plumes, and Paradigms 217-247 (2005).

22. Lambart, S., Laporte, D. \& Schiano, P. Markers of the pyroxenite contribution in the major-element compositions of oceanic basalts: Review of the experimental constraints. Lithos 160-161, 14-36 (2013).

23. Niu, Y. L. \& O'Hara, M. J. Global correlations of ocean ridge basalt chemistry with axial depth: A new perspective. Journal of Petrology 49, 633-664 (2008).

24. Fan, Q. C. \& Hooper, P. R. The Cenozoic Basaltic Rocks of Eastern China Petrology and Chemical-Composition. Journal of Petrology 32, 765-810 (1991).

25. Barry, T. L. et al. Petrogenesis of Cenozoic basalts from Mongolia: Evidence for the role of asthenospheric versus metasomatized lithospheric mantle sources. Journal of Petrology 44, 55-91 (2003).

26. Liu, Y. S., Gao, S., Kelemen, P. B. \& Xu, W. L. Recycled crust controls contrasting source compositions of Mesozoic and Cenozoic basalts in the North China Craton. Geochimica Et Cosmochimica Acta 72, 2349-2376 (2008).

27. Hunt, A. C. et al. Cenozoic Volcanism on the Hangai Dome, Central Mongolia: Geochemical Evidence for Changing Melt Sources and Implications for Mechanisms of Melting. Journal of Petrology 53, 1913-1942 (2012).

28. Asimow, P. D. \& Langmuir, C. H. The importance of water to oceanic mantle melting regimes. Nature 421, 815-820 (2003).

29. Chen, Y., Zhang, Y. X., Graham, D., Su, S. G. \& Deng, J. F. Geochemistry of Cenozoic basalts and mantle xenoliths in Northeast China. Lithos 96, 108-126 (2007).

30. Ho, K. S., Chen, J. C., Lo, C. H. \& Zhao, H. L. Ar-40-Ar-39 dating and geochemical characteristics of late Cenozoic basaltic rocks from the Zhejiang-Fujian region, SE China: eruption ages, magma evolution and petrogenesis. Chemical Geology 197, 287-318 (2003).

31. Xu, Y.-G., Zhang, H.-H., Qiu, H.-N., Ge, W.-C. \& Wu, F.-Y. Oceanic crust components in continental basalts from Shuangliao, Northeast China: Derived from the mantle transition zone? Chemical Geology 328, 168-184 (2012).

32. Pilet, S., Baker, M. B. \& Stolper, E. M. Metasomatized lithosphere and the origin of alkaline lavas. Science 320, 916-919 (2008).

33. Gaetani, G. A. \& Grove, T. L. The influence of water on melting of mantle peridotite. Contributions to Mineralogy and Petrology 131, 323-346 (1998).

34. Wang, X.-C. et al. Temperature, Pressure, and Composition of the Mantle Source Region of Late Cenozoic Basalts in Hainan Island, SE Asia: a Consequence of a Young Thermal Mantle Plume close to Subduction Zones? Journal of Petrology 53 , 177-233 (2012).

35. Herzberg, C. \& Asimow, P. D. Petrology of some oceanic island basalts: PRIMELT2.XLS software for primary magma calculation. Geochemistry Geophysics Geosystems 9, Q09001 (2008).

36. Lambart, S., Laporte, D. \& Schiano, P. An experimental study of pyroxenite partial melts at 1 and 1.5 GPa: Implications for the major-element composition of MidOcean Ridge Basalts. Earth and Planetary Science Letters 288, 335-347 (2009).

37. Lambart, S., Laporte, D., Provost, A. \& Schiano, P. Fate of Pyroxenite-derived Melts in the Peridotitic Mantle: Thermodynamic and Experimental Constraints. Journal of Petrology 53, 451-476 (2012).

\section{Acknowledgements}

The original manuscript benefitted from informal reviews and comments from $\mathrm{C}$. Herzberg, D.L. Anderson, and D.C. Presnall. We thank Z.H. Luo, C. Song, X.W. Li, J. L. Zhou, and L.L. Cheng for discussions. We also thank F. Albarede and editors for reviews and comments. Funding for this research is from the State Key Laboratory of Geological Processes and Mineral Resources, China University of Geosciences (GMPR201031) and the Fundamental Research Funds for the Central Universities (2011PY0157). 


\section{Author contributions}

Z.F.Y. conceptualized the original idea, performed the calculations, and wrote the original draft paper. Z.F.Y. and J.H.Z. compiled the data set, interpreted the results, and prepared the manuscript.

\section{Additional information}

Supplementary information accompanies this paper at http://www.nature.com/ scientificreports

Competing financial interests: The authors declare no competing financial interests. License: This work is licensed under a Creative Commons

Attribution-NonCommercial-ShareAlike 3.0 Unported License. To view a copy of this license, visit http://creativecommons.org/licenses/by-nc-sa/3.0/

How to cite this article: Yang, Z. F. \& Zhou, J. H. Can we identify source lithology of basalt? Sci. Rep. 3, 1856; DOI:10.1038/srep01856 (2013). 